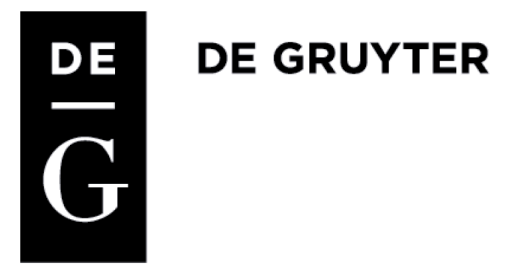

\title{
PROFESSIONAL NEGLIGENCE, MISMANAGEMENT AND MALPRACTICE. POLISH COMPANIES IN THE LIGHT OF SUPREME AUDIT OFFICE MATERIALS IN THE YEARS 1976-1980
}

The birth of the "Solidarity" Independent Self-governing Trade Union in 1980 was accompanied by a strong revisionist movement. The Polish society expected punishment for the previous administration, led by Edward Gierek, as it was their policy up to that point that resulted with enormous external debt and ubiquitous shortages of consumer goods. A lot was said about wastefulness, corruption and professional negligence, both in the state administration and in the managements of Polish companies. And these opinions were somehow justified, as evidenced by the results of audits performed by the Supreme Audit Office (Najwyższa Izba Kontroli, NIK) in the years 1976-1980. Information recorded in the audit documentation was in line with the social attitudes. Due to formal and legal conditions back then, NIK auditors could not inspect the most important companies, however they managed to prove that the scale of illegal actions committed by directors and managers was large and increased year by year.

Keywords: Poland 1976-1980, state control, national companies, management.

doi:10.1515/sho-2016-0009

\section{INTRODUCTION}

The Supreme Audit Office (NIK) was the key supervisory institution in Poland, therefore, materials prepared by its auditors are very useful when investigating the problem of financial crime. During their statutory auditory activities, the inspectors detected various negative incidents, which were evidence that some aspects of operation of Polish companies, cooperatives and budgetary institutions were of a criminal or quasi-criminal nature. Many of these problems were the fault of the management though dysfunctions in public institutions and the abnormal behavior of 
the authorities, although were nothing new, they achieved a whole new level at that time [Jarosz M. 2004: 42]. This was evidenced by a particularly strong revisionary movement in the first sixteen months of the existence of "Solidarity", in the years 1980-1981, when the society sought revenge for frauds and private criminal activities that people in broadly understood "positions of power" were involved in. This circumstance begs the question - what had actually happened before that time? Did NIK inspectors, during audits, detect the fact that managerial staff abused their positions and were guilty of mismanagement? It must be noted at this point that from the year 1976, NIK was subordinated to the Prime Minister, which significantly limited its authority, planning capabilities and the course of the audits performed [Sierpowska I. 2004: 55-56; Sylwestrzak A. 2006: 90; Konaszyc A. 1978: 96-100]. Furthermore, the fact that this problem was not noticed in literature on financial crime in Poland is an additional encouragement to investigate it [Jarosz M. 2004: 236]. This subject was either ignored or belittled [Górniok O. 1986: 101].

\section{NEGLIGENCE OF PROFESSIONAL DUTIES}

Polish companies in the years 1976-1980 functioned in the conditions of state-controlled economy, whose priority was the implementation of the economic plan. In the course of this implementation, many illegal acts were committed, including excessive tolerance towards negligence of professional responsibilities and false reporting. The gap between the official policy of fighting with these problems and the actual impunity of those who committed similar acts meant that the problem kept escalating [Karklins R. 2009: 134-137]. According to NIK, one of the main reasons why the audited companies incurred losses was the fact that the system of professional supervision was poor and the enforcement of responsibility for mistakes in company management - inconsistent. This resulted from the fact that in state-controlled economy, the division of responsibilities in particular units of the organization was not clearly defined, particularly in smaller plants [ANIK (Archive of Supreme Audit Office), GP (President's Office), 294/1, f. 2]. Furthermore, the managers did not use their authority to punish those guilty of negligence due to general problems with employment. On the other hand, on the level of ministries, associations or similar units, unreliable reports and information on 
the alleged economic achievements of companies were very often accepted indiscriminately.

Weaker supervision in this respect results from the fact that also the superior units wanted to present economic results as better than they actually were [ANIK, GP. 1627/7l, ff. 248-249].

Improper wage bill management was one of the aspects of managerial negligence frequently pointed out by NIK auditors. For example, in 1979, the "Organika-Azot" Chemical Plant in Jaworzno overstated the execution of the production plan and paid workers undue bonuses in the amount of 6.4 million PLN. The "Stomil" Rubber Company in Wolbrom made similar undue payments totaling 3.2 million PLN. The director of the Light Industry Construction Company in Dzierżoniów forged documents concerning the works performed, the overtime worked etc. The money he made this way was split with other conspirators operating in the company [ANIK, GP, 148/14, f. 25; 294/1, f. 12]. Although formally this behavior was heavily punished: e.g. with immediate termination of employment, termination of employment with notice, transfer into a different position with different working conditions and salary, a fine, referring the matter to a penal and administrative court, and, in exceptional circumstances, reporting the matter to law enforcement agencies, the problem was recurring.

The audits showed that insufficient professional supervision or even abnormalities in its functioning in terms of wage bill management (paying undue base salaries, benefits, bonuses and awards) was also the problem in state-controlled agricultural farms. Particularly shocking arbitrariness and violations were observed in 1979 in the Agriculture and Food Cooperative in Szczekociny (Częstochowa region). Manipulations in the number of daily rates in the period from July 1978 until December 1979 meant that this company paid 18 people 10.7 million PLN. Notably, the cooperative did not turn a profit in 1979, and thus obtained a 21.5 million PLN subsidy from the state budget. The director of the company singlehandedly made decisions concerning bonuses and awards, without the approval of the general meeting. He was also the main recipient of the money distributed this way. Another problem was the fact that managerial staff were paid undue compensation for using their private cars for professional purposes. In the whole of 1979, it was 600,000 PLN for 9 people, out of which 360,000 PLN went into the director's pocket. In the following year (from January until September), the aforementioned director also 
granted himself another 211,000 PLN by way of such compensation despite being on sick leave at that time [AAN (Archive of New Files), PZPR (Polish United Workers' Party), 4014, ff. 133-134].

According to NIK, improper professional supervision was the weakest link in company management in Poland. This malfunction entailed further adverse consequences: poor work discipline (drinking alcohol at work, thefts, bad performance), fictional turnover, substituting allegedly used machines with operational ones while decommissioning them, lack of supervision with regards to materials used in production (in food industry this meant creating surpluses of e.g. coffee or meat which were not recorded anywhere). The latter problem was related to illegal transactions in fluid fuels. How could it be any different, though, if e.g. in the "Wega" Wool Company in Bielsko-Biała an audit of drivers' logs performed by NIK inspectors showed that they reported different distances covered on the same Bielsko-Biała - Straconka route: 20, 23, 38, 48, 50, and even 61 $\mathrm{km}$, while the actual distance is $12 \mathrm{~km}$ [ANIK, GP, 1569/10, f. 417]? This was not an isolated case of course. NIK assessed that the worst situation in terms of fuel turnover was observed in agriculture. Tests showed that, officially, farmers bought only $10-15 \%$ of the fuel needed, and "presumably obtained the rest of the fuel needed from illegal sources" [ANIK, GP, 1569/12, f. 56].

A clear proof of the terrible state of management in Polish companies was the frequency of sham reporting. In any case it had to be at least tolerated, and quite probably, even inspired by directors, managers, and presidents. In the $4^{\text {th }}$ quarter of 1977 , and in the $1^{\text {st }}$ and $2^{\text {nd }}$ quarters of 1978 , out of 323 companies audited in this respect, in 234 (72\%) unreliable and inaccurate reports were found. The problem was therefore much more serious that the Central Statistical Office reported - according to them, 10\% of reports contained data inconsistent with the records found in source documentation [ANIK, GP, 1627/4, f. 16]. It must be added that the problem of false reporting concerned all companies: small and large, new and long established, from agricultural cooperatives to coal mines. By manipulating reports, the management usually tried to conceal problems with implementing the production plan or achieving the planned level of income.

Large scale manipulations were reported in national agricultural companies and farmers' cooperatives. Data regarding the number of livestock were falsified, its value was manipulated, also fictional renovations and irrigation works were reported [ANIK, GP, 294/3, f. 27]. Some mines hid 
their problems with executing coal extraction plans in the same way. This was the case for example in the "Generał Zawadzki" mine, which in just 5 months of 1980 issued 223 fictional invoices, claiming to have sold 189,000 tons of coal worth 41.5 million PLN. Other mines hid the fact that their yield was lower than expected by overestimating own usage of coal and its alleged stock in heaps [AAN, PZPR, 4014, f. 16]. The record in this respect was probably held by the Jelcz Car Company, which unjustly included 479 cars worth 333 million PLN in their production figures for the year 1976, while some of the cars were sold as late as April 1977 [ANIK, GP, 1627/3, f. 367]. Dismissal of three vice presidents of the Jelcz company and of several employees responsible for the incorrect reports proved that NIK findings were correct. NIK also made a request to reconsider the employment of the chief director of the company because, clearly, he neglected his professional duties. For similar reasons, based on NIK findings in 1979, the prosecutor's office arrested the chief director of the "Organika Azot" Chemical Company in Jaworzno [ANIK, GP, 148/14, f. 27].

\section{ABUSES}

One of the most prevalent problems in Polish companies was the abuse of managerial positions for private purposes. In this respect, the behavior of the management of the Radio and Television Committee was particularly telling. The audit in the Committee began in April 1980, because previous proceedings initiated in 1977 and 1979 had been suspended upon the request of the Prime Minister. NIK accused the management of this institution of diminishing currency-related income to the state budget [AAN, PZPR, 4014, f. 147] and incurring losses as a result of unreasonable currency purchases, including those made for personal benefit [Lesiakowski K. 1998: 418]. In particular this involved the creation of two companies abroad by the management of the Committee. Foreign cooperators made payments due for broadcasts (for example from the Pope's visit in Poland) and for commissioned films and television programs to the accounts of these companies. From May 1979 until September 1980, these payments amounted to USD 1.6 million, which the Committee's management had at their free disposal. NIK also questioned the purchase of equipment and personal items from the so-called $2^{\text {nd }}$ payment area, without an in-depth analysis of needs and justification of the purchase: 
As a result, a large part of purchased items made was either not used or used very little. Some were handed over to the management or other employees of the Committee for their personal use [AAN. PZPR, 4014, f. 149].

This included sports equipment, radio and television equipment, cassette recorders or calculators. Based on the results of the audit, NIK made a request to the prosecutor's office to initiate penal proceedings against the management of the Committee [Komisja 2013: 309].

NIK also reported massive abuses by and privileging of the people in power in the housing construction industry. The situation in this sector was difficult - in the late 1976 in Poland there were 700,000 members of housing cooperatives waiting for flats [Jarosz D. 2010: 258] - which gave rise to abuses in institutions making decisions on flat allocation.

The people responsible for allocating flats were found guilty of non-compliance with the transparency of allocation procedures and of excluding some flats from social supervision [ANIK. GP, 1569/6, f. 228].

For example, the construction of 13 single-family detached houses by the Housing Cooperative in Rzeszów for selected employees of the Agricultural Construction Association in Rzeszów and associated companies had criminal features. Furthermore, interested workers of the Association, including the director and his two deputies, led to a situation where the executive companies set the house prices clearly below the actual costs of construction [ANIK, GP, 1627/3 f. 75].

Similar problems, including allocating flats to ineligible people or privileging people in positions of power, occurred during allocation of flats from the so-called company pool. In 1978, NIK inspectors established that the "Stomil" Automotive Rubber Company in Dębica allocated a dozen or so flats to workers who had already received their own cooperative flats. Even more shocking evidence for privileging the management was found in the Industrial Construction Company No. 1 in Wrocław. The construction of 14 single-family homes for the managerial staff of the company and other associated entities (including the Construction Association) consumed $77 \%$ of the total number of working hours in all sites, despite the fact that this investment comprised only $9 \%$ of the total housing construction plan of the company until the end of 1976. As a result, in the $1^{\text {st }}$ quarter of 1977, the construction of the 14 houses was finished, but none of the 214 flats in multi-family buildings for the employees of the company were built until the middle of the year, even though, according to the plan, 90 flats should 
had been finished a year earlier, that is by July 30, 1976. Notably, the houses for directors were built in a much better standard than stipulated in the design and pricing documentation [ANIK, GP, 1627/3, f. 331-332].

The problems indicated in NIK reports also included irregularities in allocating construction and recreational plots. After an audit conducted in 1977 in the Land Management and Environment Protection Department at the Regional Administration Office in Szczecin, the director of this institution was dismissed. Also in Ełk the scale of abnormalities in sales of plots for building single-family homes was so large that the head of the city had to be replaced [ANIK, GP, 294/3, f. 31; 294/4, k. 26]. NIK inspectors also noticed quite a commotion regarding allocating plots in Piastów, near Warsaw. These were allocated to people whose housing needs had already been satisfied elsewhere. Also the order of examining the requests was not observed, and the value of the property or plants located in plots was underestimated [ANIK, GO, 294/5, f. 47]. Later, it turned out that the problem escalated, and that people from the highest party and state administration positions took part in this despicable criminal activity.

According to NIK materials, another consequence of the directors' or managers' acquisition of plots was subsequent use of the production capabilities of their mother companies and their materials for building private residential and recreational houses. This was done, for example, by the director and the main engineer of the "Orzeł Biały" Mining and Foundry Company in Piekary and the director of the "Lenko" Linen Company in Bielsko-Biała [ANIK, GP, 294/1, f. 13, 16; 294/4, f. 17]. In this situation, it is hardly surprising that companies which fundamentally sponsored the construction investments of the "elites" generated massive losses. For example, the "Insbud" Construction Cooperative in Suwałki lost 18 million PLN in similar circumstances in the year 1978 and the 6 months of the year 1979. Interestingly, when the company's main accountant, probably unwilling to permanently endorse giving away construction materials to individuals for free or at wholesale prices and underestimating payments for the single-family homes built, informed her superiors of this situation, she lost her job and was dismissed from the PZPR. Only after NIK had been alarmed and had performed a new audit, the scale of abnormalities in "Insbud" was confirmed, leading to the dismissal of the cooperative's director and several other people [ANIK, GP, 294/5, ff. 48-49]. How could it have been any different, though, if the Minister of Construction and Construction Materials Industry himself, Adam Glazur, was such a bad role model? When building his own recreational house, he used materi- 
als and workers from various companies worth 1.7 million PLN without any authorization. In October 1972, he was sentenced to 7 years in prison and the house was confiscated by the Treasury [Seidler B.1988: 380, 389]. Edward Gierek, until September 1980 the First Secretary of the Polish United Worker's Party Central Committee, managed to avoid conviction, though. Based on NIK materials, the prosecutor's office accused him of spending money from the funds of the Regional Entertainment Park Construction Committee in Chorzów on his residential house in Katowice [Gajdziński P. 2014: 343].

Investigation of the large-scale use of state company resources for building private residential and recreational houses of prominent people was started by NIK in accordance with the resolution of the $6^{\text {th }}$ Plenary Session of PUWP Central Committee of October 6, 1980, which obliged NIK and the state financial supervision institutions to verify the financing sources of all dubious private construction investments executed in the 1970s - and in particular all single-family homes (apart from those in agricultural farms) and recreational houses. For this purpose, the president of NIK, Mieczysław Moczar, appointed a special team headed by Władysław Pilatowski, a member of the Chamber's council. The team operated until June 30, 1981. 7149 investments were investigated, out of which 2819 $(39.4 \%)$ belonged to people in managerial or administrative positions, including the First Secretary, 2 Central Committee secretaries, 23 first secretaries of Regional Committees, 34 secretaries of Regional Committees, 7 deputy prime ministers, 18 ministers, 31 deputy ministers, 21 governors and 31 deputy governors [Smith H., Smolar A., Wosleński M. 1983: 19]. 3422 people were found guilty $(47.9 \%)$, including 2245 (79.6\%) in prominent positions [Korupcja 1983: 148-206; Mac J. S. 1981: 5; ANIK, GP, 148/1, ff. $14-14 v ; 148 / 2$, f. 8]. This meant that the scale of abuses by prominent people in the area of private construction was particularly large.

Abuse of authority and positions for personal purposes went beyond matters related to the construction of residential and recreational houses. It also involved the use of company cars, tools, typewriters, recorders, loudspeakers or portable television sets for private purposes. Another example of abuse was the use of managerial positions to arrange foreign trips. In 1979, the aforementioned agriculture and food company in Szczekociny financed a trip to Canary Islands for three people who were not employees of the company, including the daughter and the son-in-law of the company president [AAN, PZPR, 4014, f. 134]. In the case of the management of the Residential Construction Company in Kielce, which, for two years, 
organized trips to Bulgaria for privileged employees, the "only" problem was the fact that these trips were settled from the social fund as domestic trips. In 1977, the management of the Poultry Company in Prochów financed foreign trips - and to be more precise, a voyage on the "Stefan Batory" cruise ship for 13 white-collar workers, including 9 people in managerial positions - from the company's current assets.

NIK also noticed the problem of bribery. In its classic form, it occurred when state institutions met private business. This was evidenced by convicting, in 1979, two deputy presidents of the "Lech" Leather Goods Company in Poznań, to 1.5 and 1 year imprisonment and fines of 20,000 and 80,000 PLN, for having accepted a 180,000 PLN bribe for selling acrylic imported from France to private manufacturers [ANIK, GP, 148/14, f. 28].

A specific form of bribery involved "gifts" from directors and managers to their superiors and more important cooperators. The fact that those who were receiving those gifts due to their positions treated them as their private property and not the property of the company they represented was even more telling:

The court you had was the court you could afford. The higher you are, the larger your court, and the more substantial the privilege at your disposal [Seidler B. 1988: 412].

This criminal business thrived in particular - as it was revealed by an audit in 1980 - in the Radio and Television Committee. The management of the Committee presented selected people with gold and silver watches and pens and valuable works of art, while - by means of comparison - the "Sintur" Invalid Cooperative in Turek in 1977 gave away only tapestried bed covers, rugs and decorative throws. This indicates that the mechanism of giving and accepting "gifts" was common, and the value of those items depended on the company's capabilities, but surely this phenomenon cannot be justified by the Polish society's fairly tolerant attitude towards similar behaviors at the time [Kutyłowski A., Rzepliński A. 1981: 152-154]. On a similar basis, the "Silesian Insurgents" Coking Plant in Zdzieszowice (as revealed during an audit in 1978) gave away crystals and paintings that had been bought earlier, and the management of the Copper Mines and Foundries Company in Lubin, which had more resources, gifted silver items worth almost 500,000 PLN that had been specially manufactured in the company's prototype workshop [AAN, PZPR, 4008, f. 9; ANIK, GP, 294/4, ff. 4-5; 294/3, ff. 16-17, 23]. 


\section{MISMANAGEMENT}

The information materials drafted by NIK in January 1977 reported that the actual losses resulting from mismanagement and wastefulness were much higher than what the Prosecutor's General Office had found, amounting to around 750 million PLN a year. NIK admitted, though, that a large part of the losses was hard to establish, because the system of registration, settlements and supervision in production and sales made it possible to include them into operational costs of the companies. As a result, the manufacturing or trading costs in companies grew, but the increase did not affect the assessment of their activity in the form of general financial results, because many of them achieved or even exceeded the results planned. However, this was not due to rational management or decreasing prime costs, but, for example, to price manipulation and falsifying the quality and types of resources and materials [ANIK, GP, 1627/3, ff. 60-61].

The most frequently encountered examples of mismanagement, very often punishable by law, included: making irrational and unnecessary purchases of machines and tools (including imports); insufficient protection of property; not issuing the required documents for materials and resources sold and dispatched from warehouses; unjustified settling of materials at underestimated prices; using improper technologies in production (e.g. during roadworks); improper storage or processing of agricultural products; neglect of livestock in cooperative and state agricultural farms.

When it comes to buying equipment for foreign currency it must be noted that the "Pioma" Mining Equipment Company in Piotrków Trybunalski was particularly careless. An audit in 1976 showed that the company bought in West Germany three complete welding stations for manufacturing automated machines whose production had been canceled even before the stations were imported [ANIK, GP, 2941, f. 12]. In 1979, the "Bumar" and "Energopol" Foreign Trade Companies paid in foreign currency for the import from Belgium of two completely useless prototypes of extracting machines [Rolicki J. 1990: 96] ${ }^{1}$, which were supposed to be used in Gdańsk during the construction of a refinery [ANIK, GP, 148/14, f. 27]. In this case, the NIK audit led to charging the people responsible.

1 Thus, Edward Gierek was wrong when he said many years later that during his administration, only licenses that had been implemented for production were bought. 
NIK made many mismanagement accusations towards the bosses of foreign trade centers who were responsible for negotiating prices and enforcing payments for the exported goods. The scale of the problem is evidenced by the fact that during the NIK council sitting on March 14, 1979 it was concluded that the cases of professional negligence "can be qualified as economic sabotage". Every case of such negligence led to tangible financial losses. For example the "Minex" export and import company paid its Brazilian supplier for goods (magnesite) based on the weight declared by the exporter and not the actual weight confirmed in the Polish port once the products had been unloaded. As a result, they paid USD 273,000 more than needed for the delivery of $1.6 \mathrm{t}$ of magnesite in the years 1977-1978; the money could not be recovered. Furthermore, it turned out that the bosses of trade companies sent different goods than stipulated in contracts, which also meant losses - they had to provide discounts or cover return costs. For example, the "Textilimpex-Tricot" company lost USD 150,000 after having sent to Libya 60,000 men's coats made of a different fabric than stipulated in the contract (discount). Polish companies also incurred losses by carelessly delivering products to unreliable companies. Although in 1976 the "Skórimpex" leather company had not received payment of SEK 92,400 for shoes delivered to a Swedish company, the following year they sent another batch of shoes to the same buyer [ANIK, GP, 1569/8, ff. 465-568]. Negotiation of prices for exported goods was also often neglected. In the years 1977-1978, the "Unitra" Foreign Trade Company exported silver powder at a price that did not cover the raw material and production costs. The conduct of the "Ciech-Siarkopol" sulfur company was also despicable - not only was the research of foreign market limited to information provided in the bi-monthly trade magazine "Sulphur", but also, despite actual increase in sulfur prices in 1978, the company sold it at lower prices than in the previous year [Rurarz Z.1990; f. 59; ANIK, GP, 1569/8, ff. 467-468].

What is more, NIK also pointed out serious irregularities with regard to organizing foreign business trips. These trips were planned in a particularly extravagant way. Some were completely unnecessary, as evidenced by the actions of the "Kolmex" foreign trade company, which in July, August and September of 1976 sent three consecutive teams to Turkey in order to prepare a tender proposal for delivering Diesel locomotives for this country - even though it had been known from the very beginning that the Polish party could not enter the tender because they were not able to offer engines as powerful as the Turks required. Another problem was 
the fact that, as found during audits, teams were too large and included unnecessary employees, for example, too many members of the management. In 1977, a NIK report stated that in some cases, directors spent over 100 days abroad! [AAN, PZPR, 3852, ff. 44-45; ANIK, GP, 1569/12, ff. 564, 568]. If we add that some of these trips were organized at the expense of foreign companies, but prior to signing the contract, then the situation must have risen suspicion of corruption [Madej K. 2003: 262].

\section{PERSONAL RESPONSIBILITY IN THE LIGHT OF NIK AUDITS}

Identifying those personally responsible for the detected cases of negligence, abuses and mismanagement was very difficult for auditors. It was much easier to say that the situation is abnormal and define the consequences than to specify who should be held responsible (professionally, legally and financially). Difficulties in this respect resulted mainly from poor organization and functioning of companies, a complicated (collective) decision-making processes and the weakness of professional supervision.

In many cases obstacles were created by informal, local groups of a criminal nature, the so-called cliques [Górniok O. 1986: 65-66]. This is evidenced by the case of punishing those guilty of delivering bad meat products in the Nisk Meat Company (including return of exported canned ham worth 2.7 million PLN). The district unit of NIK in Rzeszów made requests to punish the company's management twice, in 1978 and 1979. The first time, the prosecutor's office discontinued proceedings, and the second time, no verdict was given due to the amnesty. Only the third attempt proved effective. The vice director of the company for production was sentenced to two years in prison (verdict suspended for 3 years) and a 30,000 PLN fine, and the export production manager - to 1 year and 6 months in prison (verdict suspended for 3 years) and a 20,000 PLN fine. However, it was impossible for NIK to lead to the dismissal of the manager in the "Wasiułki" brick company (the worst unit of the Construction Ceramics Company in Olsztyn), which, as a result of numerous acts of negligence, for a long time introduced bricks of very bad quality to the market. The manager was defended by the Polish United Workers' Party committee in Nidzica and the Workers Council [ANIK, GP, 148/14, f. 27]. NIK also failed to enforce professional 
punishment (not to mention any other consequences) for people from the so-called research and extraction coal mine in the Lublin region who allowed for shaft deepening works to be conducted contrary to the applicable technological and geotechnical procedures, which resulted in a temporary flooding of the mine in October 1979 [AAN, PZPR, 4014, f. 18].

Despite similar obstacles, NIK managed to enforce personal responsibility in many cases. If the shortage caused by mismanagement or wastefulness was qualified as "significant", then the case was transferred to law enforcement agencies [ANIK, GP, 1586/6, f. 5]. ${ }^{2}$ In 1979, NIK audited 7769 units. 5396 people were sanctioned for abuses and mismanagement proved during audits. Professional sanctions were applied against 4624 people, including 803 directors, deputy directors and main accountants. 58 people were dismissed immediately (including 24 directors and deputy directors), 350 were dismissed with notice, 312 people (including 78 directors and deputy directors) were transferred to different positions with different salaries. Furthermore, 85 cases were transferred to prosecutor's office as qualifying for a criminal investigation. NIK also imposed 772 fines in the total amount of 3.2 million PLN.

In 1980, NIK also imposed professional sanctions against 4872 people, out of whom 777 were in managerial positions. In total, 460 people were dismissed, out of whom 100 without notice. Fines in the total amount of 3.4 million PLN were administered towards 807 people found guilty, including 397 in managerial positions. Furthermore, 180 cases were transferred to the prosecutor's office [AAN, PZPR, 4014, f. 9].

\section{CONCLUSIONS}

The aforementioned data show that NIK had proven criminal inclination among part of the Polish managerial staff in the second half of the 1970s, before the problem was publicized by "Solidarity". The number of people in managerial positions who were punished professionally, financially, by dismissal or by request for launch of a criminal investigation by the prosecutor's office gradually increased. Auditors concentrated mainly on lower ranking managers, though - at company, cooperative or commu-

\footnotetext{
2 Shortage was referred to as "significant" on the basis of comparison between its size and the overall stock of the goods that the perpetrator supervised or managed.
} 
nal levels. Managers in higher positions - in associations and ministries guilty of professional negligence, abuses and mismanagement on a much larger scale than those lower in the hierarchy, were beyond the reach of NIK auditors due to formal considerations (as NIK reported to the Prime Minister). Even more important is the fact that the government and individual ministries did not draw any conclusions from this information. Therefore, NIK audits were not an effective preventive measure and did not lead to any significant decrease in criminal practices among the directors and managers of Polish companies.

\section{BIBLIOGRAPHY:}

ARCHIVE MATERIALS

Archiwum Akt Nowych (Archive of New Files, AAN) - Polska Zjednoczona Partia Robotnicza (Polish United Workers' Party, PZPR), sign. 3852, 4008, 4014

Archiwum Najwyższej Izby Kontroli (Archive of Supreme Audit Office, ANIK) - Gabinet Prezesa (Chairman's Office, GP), sign. 148/1, 148/2, 148/14, 294/1, 294/3, 294/4, 294/5, 1569/6, 1569/8, 1569/10, 1569/12, 1586/6, 1627/3, 1627/4, 1627/7, 2941

ANIK - GP, sign. 294/1, Information on the mode of examining and handling complaints and requests sent to NIK in 1976, February 1977, f. 22.

ANIK - GP, sign. 1627/7, Responsibility in the light of NIK audits, September 7, 1978, ff. $248-249$.

ANIK - GP, sign. 148/14, Information on problems resulting from the report of Prosecutor General and NIK cooperation with law enforcement agencies in 1979, March 1980, f. 25; ibidem, sign. 294/1, Information of the mode of examining and handling complaints and requests sent to NIK in 1976, February 1977, f. 12.

AAN - PZPR, sign. 4014, Report on NIK operation in the year 1980 [1981], ff. 133-134.

ANIK - GP, sign. 1569/10, Information on the results of personal management audit, June 1978, f. 417.

ANIK - GP, sign. 1569/12, Information of NIK council on the results of the audit on expanding and efficiency of operation of liquid fuels and oil distribution network in the country, October 4, 1978, f. 56.

ANIK - GP, sign. 1627/4, Information on the results of the audit of accuracy of statistical reports, June 1978, f. 16.

ANIK - GP, sign. 294/3, Information on the mode of examining and handling complaints and requests sent to NIK in 1977, February 1978, f. 27.

AAN - PZPR, sign. 4014, Report on NIK operation in the year 1980 [1981], f. 16.

ANIK - GP, sign. 1627/3, A note to the President of the Council of Ministers regarding some conclusions from the audit, October 8, 1977, f. 367.

ANIK - GP, sign. 148/14, Information on problems resulting from the report of Prosecutor General and cooperation between NIK and law enforcement agencies in 1979, March 1980, f. 27.

AAN - PZPR, sign. 4014, Report on NIK operation in the year 1980 [1981], f. 147.

AAN - PZPR, sign. 4014, Report on NIK operation in the year 1980 [1981], f. 149. 
ANIK - GP, sign. 1569/6, Information for NIK council on some important housing problems in the light of analyses and audits performed by NIK, May 1977, f. 228.

ANIK - GP, sign. 1627/3, A note to the President of the Council of Ministers regarding some conclusions from the audit, October 8, 1977, f. 75 .

ANIK - GP, sign. 1627/3, Information on the condition of collective property protection against abuses, wastefulness and mismanagement, January 1977, ff. 331-332.

ANIK - GP, sign. 294/3, Information on the mode of examining and handling complaints and requests sent to NIK in 1977, February 1978, f. 31; ibidem, sign. 294/4, Report on complaints handled in 1978 r., February 1979, f. 26.

ANIK - GP, sign. 294/5, Report on complaints and requests handled in the year 1979, [1980], f. 47.

ANIK - GP, sign. 294/1, Information on the mode of examining and handling complaints and requests sent to NIK in 1976, February 1977, f. 13, 16; ibidem, sign. 294/4, sign. 294/4, Report on complaints handled in 1978, February 1979, f. 17.

ANIK - GP, sign. 294/5, Report on complaints and requests handled in the year 1979, [1980], f. 48-49.

ANIK - GP, sign. 148/1, Decision no. 1/90 of the president of NIK, October 21, 1980, f. 1414v; ibidem, sign. 148/2, Decision no. 11 of the president of NIK, June 30, 1981, f. 8.

AAN - PZPR, sign. 4014, Report on NIK operation in the year 1980 [1981], f. 134.

ANIK - GP, sign. 294/3, Information on the mode of examining and handling complaints and requests sent to NIK in 1977, February 1978, f. 3, 16.

ANIK - GP, sign. 148/14, Information on problems resulting from the report of Prosecutor General and cooperation between NIK and law enforcement agencies in 1979, March 1980, f. 28.

AAN - PZPR, sign. 4008, A note to the president of NIK on the audit in the Radio and Television Committee [1980], f. 9; ANIK - GP, sign. 294/4, Report on complaints handled in 1978, February 1979, ff. 4-5; ibidem, sign. 294/3, Information on the mode of examining and handling complaints and requests sent to NIK in 1977, February 1978, ff. 16-17, 23.

ANIK - GP, sign. 1627/3, A note to the President of the Council of Ministers regarding some conclusions from the audit, October 8, 1977, ff. 60-61.

ANIK - GP, sign. 2941, Information on the mode of examining and handling complaints and requests sent to NIK in 1976, February 1977, f. 12.

ANIK - GP, sign. 148/14, Information on problems resulting from the report of Prosecutor General and cooperation between NIK and law enforcement agencies in 1979, March 1980, f. 27.

ANIK - GP, sign. 1569/8, Minutes of the sitting of NIK council on March 14, 1979, f. 436; ibidem, Information on the results of the audit of the efficiency of foreign trade, February 1979, ff. 465-468.

ANIK - GP, sign. 1569/8, Information on the results of the audit of the efficiency of foreign trade, February 1979, ff. 467-468.

AAN - PZPR, sign. 3852, A report from NIK operation in the year 1977 [1978], ff. 44-45; ANIK - GP, sign. 1569/12, Information the conclusions from the audit on foreign business trips [1977], ff. 564, 568 .

ANIK - GP, sign. 148/14, Information on problems resulting from the report of Prosecutor General and cooperation between NIK and law enforcement agencies in 1979, March 1980, f. 27.

AAN - PZPR, sign. 4014, Report on NIK operation in the year 1980 [1981], f. 18.

ANIK - GP, sign., 1586/6, A bulletin from NIK president, January 6, 1977, f. 5.

AAN - PZPR, sign. 4014, Report on NIK operation in the year 1980 [1981], f. 9. 


\section{LITERATURE}

Gajdziński P. (2014), Gierek. Człowiek z węgla [Gierek. A man of coal], Wydawnictwo Poznańskie, Poznań.

Górniok O. (1986), Przestępczość gospodarcza: wybrane przejawy i uwarunkowania [Financial crime: selected symptoms and conditions], Uniwersytet Śląski, Katowice.

Jarosz D. (2010), Mieszkanie się należy... Studium z peerelowskich praktyk społecznych [A house is your right... A study of social practices in the Polish People's Republic], Oficyna Wydawnicza Aspra-JR, Warsaw.

Jarosz M. (2004), Wtadza, przywileje, korupcja [Power, privilege, corruption], Wydawnictwo Naukowe PWN, Warszawa.

Karklins R. (2009), Wszystkiemu winien system. Korupcja w krajach postkomunistycznych [The system is to blame. Corruption in post-communist countries], Wydawnictwo Sic!, Warsaw.

Komisja Tadeusza Grabskiego 1981 [Tadeusz Grabski Commission 1981] (2013), Jabłonowski M., Janowski W. (ed.), Faculty of Journalism and Political Science, University of Warsaw, Warsaw.

Konaszyc A. (1978), Kontrola parlamentarna w PRL, Zakład Narodowy im. Ossolińskich [Parliamentary control in the Polish People's Republic], Wrocław-Warszaw-Kraków.

Korupcja polskiej "nomenklatury”. Z tajnych akt Najwyższej Izby Kontroli PRL [Corruption of the Polish "nomenklatura". From the secret files of Supreme Audit Office] (1983), "Zeszyty Historyczne" (Paris), no. 64, p. 148-206.

Kutyłowski A., Rzepliński A. (1981), Opinie na temat tapownictwa jako przestęstwa i zjawiska społecznego [Opinions on bribes as a crime and a social problem], [in:] "Opinia publiczna i środki masowego przekazu a ujemne zjawiska społeczne" [Public opinion and mass media and negative social phenomena], Wydawnictwo Prawnicze, Warszawa, p. $142-156$.

Lesiakowski K. (1998), Mieczysław Moczar "Mietek”. Biografia polityczna [Mieczysław Moczar, “Mietek". A political biography], Oficyna Wydawnicza „Rytm”, Warszawa.

Mac J. S. (1981), Duże pranie [Big laundry], "Prawo i Życie”, no. 28, p. 5.

Madej K. (2003), Siermiężna i dolarowa - korupcja w PRL w latach 1956-1980 [Poverty and dollars - corruption in socialist Poland in the years 1956-1980], [in:] Stola D., Zaremba M. (ed.), "PRL. Trwaniei zmiana” [SocialistPoland.Stagnation and change], Wydawnictwo Wyższej Szkoły Przedsiębiorczości i Zarzadzania im. Leona Koźmińskiego, Warsaw, p. 249-280.

Rolicki J. (1990), Edward Gierek. Replika (wywiad rzeka) [Edward Gierek. A replica (an interview)], Polska Oficyna Wydawnicza "BGW", Warsaw.

Rurarz Z. (1990), Byłem doradca Gierka [I used to be Gierek's advisor], Andy Grafik, Warszawa.

Seidler B. (1988), Ludzie i paragrafy [People and law], Wydawnictwo Literackie, Kraków.

Sierpowska I. (2003), Funkcje kontroli państwowej. Studium prawno-porównawcze [Function of state controls. A legal and comparative study], Kolonia Limited, Wrocław.

Smith H., Smolar A., Wosleński M. (1983), Władza i przywileje [Power and privileges], Oficyna WE, Warsaw

Sylwestrzak A. (2006), Najwyższa Izba Kontroli. Studium prawnoustrojowe [Supreme Audit Office. Systemic and legal study], Wydawnictwo Sejmowe, Warszawa. 
Krzysztof Lesiakowski - PhD, Profesor, who works at the Polish and World History Faculty at the University of Łódź. His main research interests include the relationship between authorities and society in Poland after the Second World War, Polish People's Republic, policy towards the young generation, Polish biographies in the 20th century. His publications include: Mieczystaw Moczar "Mietek”. Biografia polityczna [Mieczysław Moczar, "Mietek". A political biography] (Warszawa 1998); Jarocin w obiektywie bezpieki [Jarocin Festival through the lenses of the Security Services] (Warszawa 2004) (co-written with two authors); Powszechna Organizacja "Stużba Polsce" 1948-1955 - powstanie, działalność, likwidac$j a$ ", [The Common Organization "Service for Poland" (1948-1955): origin, activity, liquidation] vol. 1-2 (Łódź 2008); Strajki robotnicze w Łodzi 1945-1976 [Workers' strikes in Łódź 1945-1976] (Łódź 2008). He is also the author of numerous articles and the editor of several collected works, including Łódzki strajk studencki styczeń-luty 1981. Spojrzenie po latach" [Students' strikes in Łódź January-February 1981. A perspective after the years] (ŁódźWarsaw 2014). 
